\title{
Krasnoyarsk Water Reservoir: Monitoring, Biota, Water Quality
}

Received 2.06.2008, received in revised form 25.08.2008, accepted 27.08.2008

\begin{abstract}
This joint work generalizes the results of the Krasnoyarsk water reservoir ecological monitoring held by the faculty, researchers and students of Krasnoyarsk State Universitya (at the moment Siberian Federal University) in 1977-2005.

For the first time during the existence of the Krasnoyarsk water reservoir the many years monitoring survey resulted in the analysis of synchronously gained hydrological, hydro-chemical and hydrobiological materials; species compositions of phyto-, zooplankton, zoobenthos, periphyton have been listed; fish physiological biochemical characteristics have been given. Biota structural functioning organization, its productive-destructive dynamics have been shown. Regression equations have been calculated by quantitative link between average-vegetation and august values of the biota components' density, production and destruction. The complex evaluation of the water quality by its chemical and biological (bio-indication, bio-testing) descriptors has been done for the first time; the following systems modified for the Krasnoyarsk water reservoir have been developed: «system of saprotaxob analysis», "Woodiviss biotic index system», "Unified classifier of water quality assessment by chemical and biological values»; the ecosystem condition has been evaluated by many-year monitoring survey of phyto-, and zooplankton has been done and its ecological modifications have been determined. The mathematical aspects of the biota and water quality analysis and the computer model of the water reservoir ecosystem condition have been described for the first time.

The monograph is aimed at professionals and students majoring in hydro-ecology, fish breeding industry, experts in environmental protection and use of water resources.
\end{abstract}

\section{Strategy and Tactics of the Organization of Ecological Monitoring of the Krasnoyarsk Reservoir}

\section{Z.G. Gold, A.V. Shaposhnikov, V.M. Gold}

Discussion of various definitions of ecological monitoring and normative documents on the organization of state environmental monitoring is lead. Works on the organization and implementation of environmental monitoring to Krasnoyarsk reservoir are grouped into 4 blocks: 1 - the development of monitoring programs, grid of stations, strategies; 2 - a cycle of information-analytical work, including the establishment of the database; 3 - using of the mathematical device of an efficient estimation and forecasting of ecosystem state; 4 - formation of the block of executors - professionals.

Leading principles of monitoring are fixed: synchronism in gathering a material, maintenance of spatio-temporal parameters, automation of techniques of gathering materials, its processing, high professionalism of executors. 


\section{The Basic Characteristics of Hydrological, Hydrophysical and Hydrochemical Modes of a Krasnoyarsk Reservoir}

Z.G. Gold

The analysis of spatio-temporal dynamics of a water level, temperature, water transparency, chemical components (a mineralization of waters, water hardness, water turbidity, redox potential, $\mathrm{pH}$, $\mathrm{O}_{2}$, ammonium, nitrates, nitrites, phosphorus the general, iron, manganese, zinc, cadmium, copper, aluminium, mercury, chromium, lead, organic matters - БПК (biochemical oxygen demand), ХПК (chemical oxygen demand), BOB, oil products, CПАВ, phenols) is lead. An information role of chemical components in an estimation of water quality analyzed in chapter 5.

\section{Structural Characteristics of Krasnoyarsk Reservoir Aquatic Communities}

\subsection{High Aquatic Plant}

Z.G. Gold, E.A. Ivanova

The high aquatic plant (macrophyte) diversity in Krasnoyarsk reservoir was studied from 1978 to 2005. Macroscopic flora included the 29 species (15 families) aquatic angiosperms (flowering plants), Equisetaphyta -1, Bryophyta - 1. An aquatic plant can be defined as one that is normally found growing in association with standing water whose level is at or above the surface of the soil. The macrophytes occurred in the shallow upper part of the Krasnoyarsk reservoir.

\subsection{Phytoplankton}

E.A. Ivanova, N.N. Kojevnicova, L.A. Glushenco

The phytoplankton of Krasnoyarsk reservoir have been studied in the period from 1977 to 2005 years. The diatom, green and blue-green algae was consisted the most taxonomic diversity of phytoplankton. Maximum biomass of phytoplankton was observed in 1976, 1992, 1993 years in seasonal dynamics. The blue-green algae was blooming in July - August in surface lower (5-15 sm) of the water in the all Krasnoyarsk reservoir.

\subsection{Zooplankton}

I.I. Morozova, G. A. Enikeev, I. G. Enikeeva

Zooplankton species composition has been analyzed; the spatial temporal dynamics of its number, biomass, individual mass of zooplankton organisms as well as interconnection between August and average vegetation zooplankton density have been considered.

\subsection{Bacterioplankton}

E.Y. Muchkina

In water ecosystems planktonik bacteria are an integral functional and structural component of the plankton community.

We have been studing Krasnoyarsk Reservoirs for twenty eight years (1978 - 2005) from eighth to thirty fifth year of its functioning. In the dynamics of the numbers of bacterioplankton trough different years of analyzed time period several situations might be picked out: 
- unfil the 20 years of the functioning of the reservoir the average vegetation values of the bacterioplakton varied within the narrow rage of $1.5-2.7 \mathrm{mln}$ cell $/ \mathrm{ml}$;

- from 21 nd to 24th years of functioning of the reservoir - regular increase of the number of bacteria up to maximum of $4.5 \mathrm{mln}$ cells $/ \mathrm{ml}$;

- 25th-35th years of functioning of the reservoir - noticeable variations of the number of bacteria: the decrease down to $1.9 \mathrm{mln}$ cells $/ \mathrm{ml}$ is changed to rising up to $2.7 \mathrm{mln}$ cells $/ \mathrm{ml}$.

The seasonal dynamics of the numbers and biomass of the bacterioplankton are substantially varying though the years and different reservoir regions.

\subsection{Macrozoobenthos of the Krasnoyarsk Water Reservoir}

Z.G. Gold, G.N. Skoptseva, S.P. Shulepina

For the period of time from 1978 to 2005 (the $8^{\text {th }}-35^{\text {th }}$ years of the Krasnoyarsk water reservoir existence 224 species of bottom animals have been registered: the dominating ones among them are chironomids, sub-dominating ones are oligochaetes. They determine the formation of "soft" macrozoobenthos. The density of the bottom assemblages varies in years, grounds, decreasing by the water reservoir axis from the upper to middle area. Regression equations have been calculated by average-vegetation and august density values; they will allow calculating the average summer density by August data only in the future. Zoobenthos species zonal distribution by the depths and grounds has been determined at the sample of longitudinal sections on Krasnoturansk (the upper area), Novoselovo (the middle area) and Priplotinny (by-dam lower area) stretches of the Krasnoyarsk water reservoir.

\subsection{Zooneuston}

\section{M.I. Gladyshev}

In the paper data obtained during four sampling seasons of Krasnoyarsk reservoir using methods for investigation of marine zooneuston was considered. List of species of zooneuston of this reservoir was composed. Evidences was provided that wind did not eliminate maximum of density of zooneuston in surface film of water. Division of fresh-water zooneuston into three groups was suggested: obligatory zooneuston of pools, littoral zooneuston and universal controbionts. Dinamics of daily vertical migrations of benthoneuston in Krasnoyarsk reservoir was described in details.

\subsection{Ichthyophauna}

\section{S.M. Chuprov}

A review of materials on biology fish Krasnoyarsk reservoir for last 30 years was fulfilled. The up-to-date information about distribution, growth, reproduction, nutrition of such species as are. The content of heavy metals in the water and muscular tissue of fish was determined using the method of atomic absorption.

\subsection{Periphyton}

\section{L.A. Glushchenko, I.I. Morozova}

Within the ecological monitoring of Krasnoyarsk water reservoir conducted in years 2000-2005 the structure of periphyton (phyto-, zooperiphyton) as the component of ecosystem biota was investigation for the fist time. 
Phytoperiphyton in Krasnoyarsk water reservoir is with presented by 88 species of algae with 52 diatoms (Bacillariophyta), 9 blue-green (Cyanophyceae), 25 green (Chlorophyteae) and 2 Euglenophyta among them. The structure forming complex of phytoperiphyton was included the following sessile algae: Cymbella prostrata, Didymosphenia geminata, Cladophora glomerata and others. Zooperiphyton was represented by 22 species and forms, particularly 8 crustaceans (Crustacea), 3 rotifiers (Rotatoria), 2 dipteran (Diptera), 7 oligochaete (Oligochaetea) and 2 molusks (Mollusks). The structure forming complex of zooperiphyton was represented by Nais barbata, Chydorus sphaericus, Testudinella patina, Trichotricha truncate, Glyptotendipes gripekove.

Interannual, seasonal and regional (wide parts of the reservoir) analysis of dynamics of species diversity and density of phyto-, zooperiphyton communities in Krasnoyarsk water reservoir was conducted.

\section{Functioning of Krasnoyarsk Reservoir Aquatic Communities}

\subsection{Determination of Structurally Functional Parameters of Algal Cenosis on the Basis of Data of the Fluorescent Analysis}

N.A. Gaevsky

In this section methodical features of determination of chlorophyll $a$ concentration at three phytoplankton taxanomic groups, including diatoms, green and blue-green algae on the basis of spectral features of fluorescence are considered. Also the opportunity of definition of total phytoplankton primary production is shown.

Taxonomic structure of phytoplankton of the Krasnoyarsk reservation (August, 1982) from its riverheads to dam of hydroelectric power station is presented as frequency distribution of the share contribution of concentration of a chlorophyll and everyone taxonomic groups to the general concentration of a chlorophyll $a$.

Distribution of a chlorophyll $a$ between the basic departments of algae was heterogeneous in the top part of reservation and wass the most homogeneous in an average part of it. The site located above a dam, keeps features algal cenosis in the central part. On total concentration of a chlorophyll $a$ were allocated Krasnoturansk $\left(36 \mathrm{mg} / \mathrm{m}^{3}\right)$ and Primorsk $\left(35 \mathrm{mg} / \mathrm{m}^{3}\right)$ reaches. In most cases values of concentration concentration was within the limits of $2,5-7, \mathrm{mg} / \mathrm{m}^{3}$.

Unimodular character of distribution of sizes of total primary production with a maximum in center Krasnoturansk region of a reach and appreciable advantage of the bottom sites above top is established.

The fluorescent method has allowed to receive a detailed picture of spatial variability of structural and functional parameters phytoplankton of the Krasnoyarsk reservation during mass development of blue-green algae (August, 1982). For the characteristic of the reservation a greater degree the grouping of data on reaches, than on separate stations or on their accessory approaches the top, average or bottom areas. 


\subsection{The Krasnoyarsk Water Reservoir Plankton Components' Contribution to the Organic Matter Destruction}

I.M. Popeltitskaya

According to the results of many year investigation of the Krasnoyarsk water reservoir by various methods the plankton components' breathing and contribution into the general destruction process have been analyzed. During the monitoring research at the Krasnoyarsk water reservoir a test determining plankton components' contribution into the organic matter destruction process has been done. The test and semi-empirical methods resulted in discovering the dependence of the phyto-plankton's breathing intensity on the assemblage density and species diversity. According to the collected data the contribution of phyto-, bacterial and zooplankton into the general breathing varies in years, months and water reservoir areas. The semi-empirical method of calculation to determine the Krasnoyarsk water reservoir plankton biota components' breathing is recommended.

\subsection{Productive - destructive Characteristics of plankton and Bottom Assemblages}

Z.G. Gold

Spatial temporal dynamics of the primary and secondary production and organic matters' destruction values have been analyzed. Regression equations have been calculated by quantitative link between average-vegetation and august values of the production and losses on metabolic processes. By the data of the equations and corresponding indexes the following one-month August surveys will allow gaining average-vegetation productive - destructive values.

The following correlation coefficients have been calculated: bulk primary plankton production - destruction, secondary production - losses on metabolism processes of bacterial, zooplankton, zoobenthos; production - biomass (by all biota components). Average values of biota-proяяяяduced organic matter and its losses on metabolic processes have been calculated for the period of the Krasnoyarsk water reservoir monitoring.

\section{Water Quality and Trophic Status of the Krasnoyarsk Water Reservoir}

Z.G. Gold

Complex water quality assessment of the Krasnoyarsk water reservoir has been done in different areas by chemical descriptors (such as water pollution index, water pollution complexity coefficient) and biological ones (such as bio-indication and water bio-testing). Spatial temporal dynamics of zoobenthos, phyto- and zooplankton's saprobity indexes as well as biotic index of Woodiviss modified for the Krasnoyarsk water reservoir, levels of water toxicity determined by bio-testing (luminescent bacteria, algae, slipper animalcules) have been analyzed. The introduction of the saprotaxobity analysis has been substantiated; the lists of hydro-bionts species with individual saprotaxobity values have been given. The unified water quality classifier has been developed. By many years monitoring observations of phytoplankton and zoobenthos density values ecological modifications in various conditions of biocenosis metabolisms have been analyzed.

Trophic characteristics of the water reservoir by the bulk initial production ( $Г \mathrm{C} / \mathrm{M}^{2 *}$ сут.) and biomass of bacterial plankton, zooplankton and zoobenthos. The trophic type (eutrophic - hypereutrophic, V VII classes of increased and high food capacity) has been determined as a priority one. 


\section{Development of Automation the Information and Software for Hydrobiological Researches of the Krasnoyarsk Reservoir}

\section{B.V. Olejnikov}

Article deals with some directions and outcomes related to the establishment of software for hydrobiological research of Krasnoyarsk reservoir starting at 1980.

In particular, results concerned with the establishment of the sufficiently original dataware automation system, that works for programmable scripts - AIPS «Delta-3D», information-graphics system "Gera-2", permissive to attach data, received during the field observations, to cartographical information, as well as modeling of various biotic processes results are represented.

Worked out tabular processors for realization rapid data analysis, its preparation and declaration for further handling are submitted.

High emphasis is placed on review of missing (blank) data that can appear in hydrobiological research. Mathematical methods of reconstruction are proposed for some part of such data (missing data of the $2^{\text {nd }}$ kind).

Article also deals with developed generalized ratio of similitude that may generate different known and unknown nominal as well as metrical coefficients using parametric settings.

All considered tools were used extensively during the work with hydrobiological data of Krasnoyarsk reservoir and can be used in other studies.

\section{Mathematical Model of the Krasnoyarsk Water Reservoir Ecosystem}

V.E. Raspopov, V.A. Sapozhnikov

To investigate the Krasnoyarsk water reservoir ecosystem a three-dimensional mathematical model was developed. For the cases when the dynamic variable models depend upon time only and upon time and depth the outcomes of the computing experiments are given. It is proposed to find the indexes of the mathematical model, that are not determined experimentally, by solving reverse problems.

\section{Conclusion}

While forming the monograph "The Krasnoyarsk water-storage basin: monitoring, biota, water quality " there has been set a task to examine the Krasnoyarsk water-storage basin ecosystem as the complete, strictly organized formation all parts of which are interconnected in a certain way. Particular separate results of the survey of biotic and abiotic components have allowed to proceed to consideration of the general properties of the water basin ecosystem.

Comparability and objectivity of ecosystem components characteristics have been provided with a methodological principle of researches: they have been carried out from the seventh (1977) to the thirty fifth (2005) years of the water basin functioning, within the framework of ecological monitoring - the systems of long-term regular supervision, estimations and the forecast of antropogenic and natural changes in the environment according to specially developed programs. The ecological monitoring which is carried out in the Krasnoyarsk water-storage basin included 4 blocks:

1 - development of programs, networks of observation stations, methods and techniques of researches; 
2 - a cycle of information-analytical works, including formation of a database "Biota";

3 - search for the mathematical apparatus parameters with the purpose of creation of the tool of the operative estimation and the forecast of the water basin ecosystem condition;

4 - formation of the team of executors - professionals.

The Krasnoyarsk water-storage basin is a large deep-water reservoir generated in the upper part of the Yenisei River middle reaches: the filling of the water basin was carried out in 1967-1970, the extension in the meridional direction from the north to the south is $386 \mathrm{kms}$, at a normal pond level (NPL=243 m B.S.), the water surface area is $2000 \mathrm{\kappa m}^{2}$, the maximal width in the area of Krasnoturansk Reach is $15 \mathrm{kms}$, minimal - in the area near the dam $-2,5 \mathrm{kms}$, the maximal depth at the dam $-105 \mathrm{~m}$, average in the water basin $-36,7 \mathrm{~m}$, the water level drawdown within one year is $6-18 \mathrm{~m}$. During the formation of the water basin the most significant changes were the increase of underground backwaters, the growing character of coast rearrangement and accordingly the soil transformation. The deep-water character and the big extent of the water basin determined a discrete vertical zonality, development of horizontal heterogeneity in the distribution of temperature and transparency, the formation of a thermal bar. The photic layer depth corresponded to the depth of epilimnion.

A priority component in the system organization of the ecological system of the Krasnoyarsk water-storage basin is biota. Biota's autotrophic element including higher aquatic plants and algae is formed according to general biological laws, in terms of structure and function. Higher aquatic plants in the Krasnoyarsk water- storage basin are weakly developed, 29 species are registered. Macrophytes do not form significant thickets, they do not occupy big territories. It is caused by the small share of shoals and littoral, a high water drawdown level, by the formation of emptiness between ice and water in spring. Settling ice lumps tear off the anlages of the higher aquatic plants, the vegetation growing up along the coast by August turns out to be submerged. It seems more realistic that in the future the existing hydrological mode of the water basin would not allow macrophytes to form dense thickets in the big territories.

The species diversity of natural communities of the Krasnoyarsk water- storage basin was formed in 1977-2005 in the direction of decrease and structure simplification of phyto-zooplankton, neuston, zoobenthos and ichthyofauna; the structure-forming complexes were generated. The parameters values of the communities density were naturally reduced along the axis from the upper area to the dam, varying in the interannual and seasonal aspects.

The water bloom caused by the mass development of grey-blue algae became apparent in the sixth year of the water basin functioning (on the Krasnoturansk Reach), it amounted to maximum in the twelfth $\left(1982-5,7 \mathrm{~g} / \mathrm{m}^{3}\right)$ and the twenty third $\left(1993-4,6 \mathrm{~g} / \mathrm{m}^{3}\right)$ years of functioning. Since the 24 th year $(1994)$ the level of bloom has decreased up to Class I $\left(\mathrm{B}=0,7-0,1 \mathrm{~g} / \mathrm{m}^{3}\right)$.

In the ichthyofauna structure of the Krasnoyarsk water-storage basin 26 fish species and one representative of Agnatha (jawless animals) - the lamprey Siberian - are revealed. New species for the water basin are those which were acclimatized - the bream, the Baikal cisco, the syrok.. The carp penetrated into the reservoir from the fish-breeding ponds. The Siberian sturgeon and the sterlet are not numerous in the water basin. In comparison with the conditions which existed before the river monitoring, the diseases that were not peculiar for the fish of the water basin earlier are revealed: ligulosis, digrammosis, diphyllobothriasis, "stomach ulcer". The infection of diphyllobothriasis is noticed as a disease of such fish as the pike, the perch, the taimen, the burbot; the perch may be infected 
with "stomach ulcer". The main reason of the spread of diphyllobothriasis is the penetration of tapeworm eggs into the water basin with settlement sewage, navigable transport, animal excrements .

During the years of the intensive water "flowering" pathological changes of cells were constantly registered on the blood smears of the fish of the Krasnoyarsk water-storage basin: hypersegmentation of a nucleus, poikilocytosis, schistocytosis.

The functioning of the water basin ecosystem is determined to a great extent by the productional processes level, by the ratio of values of production and destruction of organic substance by biota. The values of total primary production of the plankton of the Krasnoyarsk water basin changed in a range: from 0,6 to $73,0 \mathrm{~kJ} / \mathrm{m}^{3}$ per day, the mean value is $15,5 \pm 0,76 \mathrm{~kJ} / \mathrm{m}^{3}$ per day. The destruction of organic substance by plankton in the water basin pelagos was equal on average to $21,53 \pm 1,41 \mathrm{~kJ} / \mathrm{m}^{3}$ per day with the amplitude of variation from 4,0 to $82 \mathrm{~kJ} / \mathrm{m}^{3}$ per day.

As a whole, according to the monitoring research materials of the Krasnoyarsk water-storage basin ecosystem (1978-1997 г.г.), it was ascertained:

- every day the plankton produces $436,89 \pm 49,34 \mathrm{~kJ} / \mathrm{m}^{2}$ per day in the water column under a square meter;

- the shares of production of organic substance by the heterotrophic component had the following distribution in the ranged line: bacterial plankton $(28,2 \%)>$ zooplankton $(0,31 \%)>$ zoobenthos $(0,02 \%)$.

- every day in the water column under a square meter (benthos on $\mathrm{m}^{2}$ )the biota spends $954,2 \mathrm{~kJ} /$ $\mathrm{m}^{2}$ per day of organic substance on the maintenance of vital processes. According to the shares of destruction values of the biota components the ranged number line had the following form: phytoplankton $(56,63 \%)>$ bacterial plankton $(42,72 \%)>$ zooplankton $(0,63 \%)>$ zoobenthos $(0,02$ $\%)$.

In the communities of plankton and benthal filter-feeders, detritophages and omnivores prevail, they provide the main stream of energy in the detrital food network. It is impossible to estimate quantitatively the streams of energy in the Krasnoyarsk water-storage basin ecosystem as a whole, as the data on the fish productional parameters is not received.

Fluctuations of structural and functional parameters did not go beyond the range limits of the evolutionary-fixated corridor. The ecosystem catastrophic changes in response to external influences had a local character, as they moved away from the source of pollution, they were quickly restored after two - three years.

According to the synchronously received file of mid-vegetation (y) and August (x) values of density, production and destruction of organic substance of bacterial plankton, phyto-, zooplankton and zoobenthos, the exponential regression equations $\left(y=a+x^{b}\right)$ with specific factors $(a, b)$ for the top, middle and bottom areas of the water basin are calculated. The equations can be used to obtain mid-vegetation parameters on one-monthly, August values, as a forecasting model. V.K.Shitikov, etc. (2005) successfully showed the importance of the forecasting character of equations by the example of the analysis of chemical and biological parameters, they noted that «... The best forecast model... is a simple regression equation » (page 275 , vol.2).

The water quality and the trophic status are determined as priority parameters in the condition estimation of the water basin ecosystem. 
The complex approach to the estimation of water quality by chemical and biological criteria is used and worked through in the Krasnoyarsk water-storage basin. The water pollution index and water pollution complexity coefficient are chosen as chemical descriptors of the water quality estimation. The excess of maximum allowable concentration (MAC) for the period from 1982 to 2005 is registered on the following components: copper - 3-8 MAC, zinc - 1-18 MAC, iron - 1-8 MAC, aluminium - 1-18 MAC, phenol - 1-9 MAC, mineral oil - 2-20 MAC. The values calculated on organic components varied in a range from 0,36 up to 0,54 points, the water being estimated as pure, I Class quality water.

The water pollution index, calculated according to a concentration complex of metals and xenobiotics, varied in a range from 1,0 points up to 5,3 points, the water being estimated as dirty in 1990, as moderate - polluted - in 2002, and polluted - in 2005.

According to biotests reactions (luminous bacteria, slipper animalcules, crustaceans), the water toxicity is registered everywhere in the water basin.

The results of saprobe analysis gave smoothed estimations of the water quality, at the level of Classes I-II, that was the consequence of incorrect values of species individual saprobity which took into account only organic pollution. More concrete estimations are given by saprotoxobity analysis uniting toxic situations and inorganic pollution.

The final conclusion about water quality on chemical and biological descriptors is suggested to be made according to the Wudivis's modified index calculation pattern and « The Unified water quality classifier », developed on a regional basis with reference to the Krasnoyarsk water-storage basin and some water-currents of the Yenisei River basin.

An ecological modification analysis was carried out on the monitoring observation lines; the Krasnoyarsk water basin ecosystem corresponds to the condition of «anthropogenic tension with eutrophication elements».

The trophic status of the Krasnoyarsk water basin is determined according to two criteria:

- total primary production value ( $\mathrm{gC} / \mathrm{M}^{2}$ per day): from the twenty seventh (1997) to the thirty fifth (2005) years of the water basin functioning trophic state stabilized at the eutrophic type level, food capacity raised, Class $\mathrm{V}\left(\mathrm{A}=1,1-2,4 \mathrm{gC} / \mathrm{m}^{2}\right.$ per day $)$;

- biomass: of bacterial plankton (trophic state corresponded to Classes III-IV, low food capacity and meso-eutrophic type); of zooplankton (trophic state corresponded to Classes II-III, very low food capacity, oligo-mesotrophic type); of zoobenthos (trophic state - Classes I-II, extremely low and very low food capacity, oligotrophic type).

The materials on the structure-functional organization of the Krasnoyarsk water-storage basin ecosystem, included in the monograph «The Krasnoyarsk water-storage basin: monitoring, biota, water quality », and the results of discussions will be certainly supplemented with the decoding of the interrelations scheme of biotic and abiotic parameters. Structure-functional and energy principles of the Krasnoyarsk water-storage basin ecosystem research within the framework of the worked through system of ecological monitoring will allow to estimate the balance of ecosystem organic substance and to determine the main laws of its functioning in the subsequent work. 